\title{
GOOD PRACTICES ON AIR QUALITY, POLIUTION AND HEALTH IMPACT AT EU LEUEL
}

\author{
Daniela-Ioana Manea ${ }^{1 *}$, Emilia Țițan ${ }^{2}$, Mihaela Mihai ${ }^{3}$, \\ Simona-Andreea Apostu ${ }^{4}$ and Valentina Vasile ${ }^{5}$ \\ ${ }^{122) 314)}$ The Bucharest University of Economic Studies, Romania. \\ ${ }^{5)}$ Institute of National Economy, Bucharest, Romania.
}

Please cite this article as:

Manea, D.I., Tițan, E., Mihai, M., Apostu, S.A. and

Vasile, V., 2020. Good Practices on Air Quality,

Pollution and Health Impact at EU Level. Amfiteatru

Economic, 22(53), pp. 256-274.

Article History

Received: 20 September 2019

Revised: 19 November 2019

Accepted: 20 December 2019

DOI 10.24818/EA/2019/53/256

\begin{abstract}
The EU's environmental policies and strategies have been developed since the 1970s and underline that the sustainable economic development and well-being of the European Union countries are based on their natural environment. They are aimed at national and global air quality regulations that support the improvement of the air quality and the health of the population.

The principal objective of this paper is to highlight the importance of the varied and complex action of the polluting environment on the organism. A convergent objective is the development of pollution management solutions and highlighting good practices for combating and reducing pollution and improving air quality.

In this regard, the results of the analysis presented in the paper indicate that a healthier environment can prevent diseases caused by polluted air and decrease the number of deaths caused by respiratory and cardiovascular diseases. This statement represents the main result obtained by applying the methods of multidimensional data analysis (factorial analysis, principal component analysis, cluster analysis) to evaluate the complexity of contemporary environmental and health challenges. On the other hand, the use of tools and examples of the good practices for implementing strategies to improve environmental factors, especially air quality, are particularly useful in creating specific policies that lead to improving the quality of the environment and, implicitly, the health of the population.
\end{abstract}

Keywords: air quality, health, pollution, good practices, multivariate analysis.

JEL Classification: I15, Q53, Q57, C38.

\footnotetext{
* Corresponding author, Daniela-Ioana Manea-daniela.manea@csie.ase.ro
} 


\section{Introduction}

Bio-economy is a more and more used notion in the European Union's sustainable development policies and strategies. Having a transsectorial character and relying on life sciences, agronomy, ecology, food science and social sciences, biotechnology, nanotechnology, information and communication technologies (ICT) and engineering, bio-economy is defined by the European Commission as the part of the economy that includes "the production of renewable biological resources and the conversion of these resources and waste streams into value-added products such as food, feed, bio-based products and bioenergy." (European Commission, 2012, p. 1)

Integration of bio-economy into areas such as health, agriculture and industry can be achieved through innovative technologies, including biotechnology, and is based on the use of renewable biomass and bio-processes (Meyer, 2017).

The challenges that motivate the sustainable development of the bio-economy are not just about ensuring food security, but also considering the possibility of a transversal approach and multidimensional approach, and optimal management of natural resources or climate change (Ronzon, et al., 2016).

This working-paper aims to outline an image of the interdependence between health, air quality and bioeconomy, for which it is also necessary to approach aspects from other areas. For example, respiratory diseases can be caused by air pollution (Arbex, et al., 2012), heavy metals can cause neurotoxic effects and global climate change can contribute to the spread of infectious diseases (Institute of Medicine (US), 2001). Internationally, environmental health issues have traditionally been addressed in the context of issues such as depletion of the ozone layer (United Nations, 1987), climate change and biodiversity (European Commission, 2018). These issues have been addressed, or at least tried, in many countries through the multilateral process, such as multilateral agreements and commissions, bilateral assistance and cooperation, private sector investments, trade, non-governmental organizations' activity, education and training (European Environment Agency, 2017).

\section{Review of the specialized literature}

The World Health Organization (WHO) defines health, as part of its constitution as "a complete physical, mental and social well-being, and not just the absence of disease or infirmity" (WHO, 1948, p. 1). The fact that the state of the environment is one of the risk factors for human health and well-being has been mentioned by the WHO in the Air Pollution Report since 1958, the Committee's main concern being to take into account the relationship between atmospheric pollution and human health. While it has been stressed that environmental degradation can have a negative impact on people's health, the lack of data and methodologies made it impossible at that time to issue specific recommendations to set standards for safe levels of human concentration (World Health Organization, 1958). Later, in 1995, the WHO Working Group on Volatile Organic Compounds (VOC) revised and updated the air quality guidelines for Europe on the qualitative and quantitative aspects of health risks associated with exposure to organic pollutants.

Reducing greenhouse gas emissions and atmospheric pollutants, thus implicitly reducing the negative environmental and health impacts, is the main advantage of using renewable energy 
for fossil fuels. One of the main indicators of the Europe 2020 Strategy is the Share of renewable energy in gross final energy consumption by sector (Eurostat, 2019).

At the same time, the concept of bio-economy - difficult to define based on one field - makes the European Union's bio-economy strategy to support interactions between economic, social or political sectors, thus creating an integrated framework for building within the EU of a coherent international monitoring system to track economic, social and environmental progress towards a sustainable bio-economy. Thus, in the European Commission report "The connection between health, environment and bioeconomy: perspectives and implications for European policies in the field of research and innovation" (2016, pp. 9-10), it by analyze the possibility of forming a safe and sustainable society based on the development of a green and circular economy.

According to the World Wide Fund for Nature (WWF) and Ecofys report (2011) (Ecofys is an international consultancy firm in the field of energy and sustainability. Since 2016 it has been integrated into the global energy segment of the Navigant group.) by the end of 2050, it is necessary for each European country to implement its legislative policies to reduce carbon emissions. Following the application of appropriate climate policies and examples of good practice, the intermediate goal (until 2020) is to reduce greenhouse gas emissions by $20 \%$.

If we want a population with better respiratory and cardiovascular health, in the short or long term, then it is necessary to apply strategies and policies to reduce the level of air pollution (Chow, et al., 2009). According to the WHO report (Pruss-Ustun, et al., 2016, p. 103) "Preventing disease through healthy environments: a global assessment of the burden of disease from environmental risks," about 8.2 out of 12.6 million deaths due to environmental degradation are due to non-transmissible diseases caused by air pollution. It is obvious that atmospheric pollution is the major environmental risk to the health of the European Union population, WHO reporting about 400000 premature deaths caused by air pollution, most of which consisting of inhabitants from urban areas (Kiesewetter, et al., 2015).

Between 30 October and 1 November 2018, the First Global Conference on Air Pollution and Health at the WHO headquarters in Geneva, organized jointly with the United Nations (UN), Climate and Clean Air Coalition (CCAC), the United Nations Economic Commission for Europe (UNECE), the World Bank and the Secretariat the United Nations Framework Convention on Climate Change (UNFCCC) took place.

One of the objectives of the conference was to reduce the number of deaths caused by air pollution by two-thirds by 2030, by initiating initiatives for the Geneva Agenda to counteract air pollution.

Besides implementing efficient transport solutions and developing a circulating economy based especially on product regeneration, with the ultimate aim of obtaining zero emission solutions, it is desirable, on one hand, to increase the awareness of the population regarding the need to reduce air pollution and, on the other hand, to improve education on the effects of air pollution on health and to use training to understand sustainable development.

Another aspect was the strengthening of health systems and the identification and implementation of policies to prevent outdoor air pollution. At the same time, actions to reduce air pollution were also analyzed to reduce and prevent non-communicable diseases. 
Exposure to air pollutants generates, in the short term, diseases of the respiratory, cardiovascular, dermatological, ophthalmological etc. (Kampa and Castanas, 2008; Makria and Stilianakis, 2008), and long-term exposure of the body to anything that is toxic in the air can lead to cancerous conditions (Nakano \& Otsuki, 2013).

At the same time, assessing the impact of climate change on health quality and increasing air quality can be done both globally and individually, depending on the availability of data and the possibility of quantifying the desired objectives, in particular the 17 UN Sustainable Development Objectives (2015).

The intensity of the association between air pollution and health effects is difficult to determine due to the complexity of time series modeling. Barnett et al. (2006) found that, when examining several polluting factors, the independent effects of each approach in multivariate models are sensitive to modeling hypotheses.

The importance of the impact of the environment on the various fields of activity also results from the focus on environmental quality assessment based on composite indicators: Environmental Performance Index (EPI) and Social Progress Index (SPI).

\section{Research methodology}

The present study is based on a multidimensional analysis that examines the overall structure of indicators, assesses the adequacy of the set of indicators, and helps to better understand the interaction between health, the environment and the bio-economy while also highlighting the benefits and barriers to bio-economy implementation in strategies on sustainable and smart development.

Initial information can be grouped and analyzed on both countries and individual indicators. In order to verify the basic data structure, within the two dimensions, and to identify classes of indicators or groups of countries - based on similar scores - appropriate methods and techniques of multivariate data analysis are used: Principal Component Analysis / Factor Analysis (PCA / FA) and Cluster Analysis (CA).

For the study will be used indicators that characterize the three areas mentioned above (Table no. 1), having as sources data Eurostat (Eurostat, 2018) and primary indicators used in the calculation of the Social Progress Index (Social Progress Imperative, 2019) and data processing is performed with SPSS.

With 51 social and environmental indicators as input data, it draws a clear picture of the quality of life, placing less emphasis on traditional indicators. Classification of individual indicators in three major dimensions of social progress: Basic Human Needs (Nutrition and Medical Care, Water and Sanitation, Shelter, Personal Safety), the Foundations of Wellbeing (Access to Basic Knowledge, Access to Information and Communications, Health and Wellness, Environmental Quality) and the Opportunity (Personal Rights, Personal Freedom and Choice, Inclusiveness, Access to Advanced Education) help to better understand the global and regional trends of social progress. On the other hand, the explanation of each field in four subcategories allows a granular analysis of the specific foundations of social progress at country level. The final score obtained by each country allows them to be classified on six levels. The top two categories, with a high level of quality of life, include 26 of the EU Member States. Bulgaria and Romania are ranked 40th and 44th in the ranking, which places 
them on level three of the six. Globally, Norway is the country where demand is in the top position, and among EU countries, Denmark and Finland are in the 4th and the 5th positions.

The Environmental Performance Index includes 24 indicators that quantify the health of the environment and the vitality of the ecosystem. The analysis of trends and environmental progress is a useful method in the efficient elaboration of strategies regarding the environmental performance, being able to offer the possibility of quantifying the degree of achievement of the sustainable development objectives (Wendling, et al., 2018).

Table no. 1: Indicators used in data analysis

\begin{tabular}{|c|c|c|c|}
\hline Item & Indicator & Source & Code \\
\hline IN1 & $\begin{array}{l}\text { Exposure to air pollution by particulate matter } \mu \mathrm{g} / \mathrm{m} 3 \text { Particulates } \\
<2.5 \mu \mathrm{m}\end{array}$ & Eurostat & sdg_11_50 \\
\hline IN2 & $\begin{array}{l}\text { Exposure to air pollution by particulate matter } \mu \mathrm{g} / \mathrm{m} 3 \text { Particulates } \\
<10 \mu \mathrm{m}\end{array}$ & Eurostat & sdg_11_50 \\
\hline IN3 & $\begin{array}{l}\text { Greenhouse gas emissions Greenhouse gas emissions (in CO2 } \\
\text { equivalent), base year } 1990\end{array}$ & Eurostat & sdg_13_10 \\
\hline IN4 & $\begin{array}{l}\text { Urban population exposed to PM10 concentrations exceeding the } \\
\text { daily limit value }(50 \mu \mathrm{g} / \mathrm{m} 3 \text { on more than } 35 \text { days in a year) } \%\end{array}$ & Eurostat & |t2020_rn200 \\
\hline IN5 & $\begin{array}{l}\text { Average } \mathrm{CO} 2 \text { emissions per } \mathrm{km} \text { from new passenger cars }-\mathrm{g} \mathrm{CO} 2 \\
\text { per km }\end{array}$ & Eurostat & sdg_12_30 \\
\hline IN6 & $\begin{array}{l}\text { Share of renewable energy in gross final energy consumption by } \\
\text { sector \% }\end{array}$ & Eurostat & sdg_07_40 \\
\hline IN7 & Greenhouse gas emissions (CO2 equivalents per GDP) & SPI $^{*}$ & \\
\hline IN8 & Eco-innovation index $(\mathrm{EU}=100)$ & Eurostat & t2020_rt200 \\
\hline IN9 & GDP per capita in PPS Index $($ EU28 $=100)$ & Eurostat & tec00114 \\
\hline IN10 & Life expectancy at birth by sex years & Eurostat & sdg_03_10 \\
\hline IN11 & $\begin{array}{l}\text { Household air pollution attributable deaths (no. deaths } / 100000 \\
\text { people) }\end{array}$ & SPI $^{*}$ & \\
\hline IN12 & $\begin{array}{l}\text { Outdoor air pollution attributable deaths (no. deaths } / 100000 \\
\text { people) }\end{array}$ & SPI $^{*}$ & \\
\hline IN13 & $\begin{array}{l}\text { Causes of death - standardised death rate by residence Diseases of } \\
\text { the respiratory system (J00-J99) Total }\end{array}$ & Eurostat & hlth_cd_asdr2 \\
\hline IN14 & $\begin{array}{l}\text { Causes of death - standardised death rate by residence Diseases of } \\
\text { the circulatory system (I00-I99) Total }\end{array}$ & Eurostat & hlth_cd_asdr2 \\
\hline
\end{tabular}

Greenhouse gas emissions $\left(\mathrm{CO}_{2}\right.$ equivalent of GDP) - emissions of carbon dioxide $\left(\mathrm{CO}_{2}\right)$, methane $\left(\mathrm{CH}_{4}\right)$, nitrogen oxide $\left(\mathrm{N}_{2} \mathrm{O}\right)$, hydrofluorocarbons (HFCs), perfluorocarbons (PFCs) and sulfur hexafluoride $\left(\mathrm{SF}_{6}\right)$ expressed in $\mathrm{CO}_{2}$ equivalents using the 100-year global warming potential found in the second report of the Intergovernmental Panel on Climate Change Assessment on GDP-PPP (Intergovernmental Panel on Climate Change, 2007). In the SPI methodology, the data is limited to 1500 records.

Household air pollution attributable deaths (no. deaths/100000 people) - quantifies deaths from indoor air pollution, including various types of pneumonia, other lower respiratory infections, trachea, bronchial and pulmonary cancers, ischemic heart disease, stroke, hemorrhagic stroke, and other types of non-ischemic stroke, chronic obstructive pulmonary disease and cataracts in 100000 people, standardized by age. 
Outdoor air pollution attributable deaths (deaths/100000 people) - is the number of deaths from industrial activity, households, cars and trucks, expressed as a rate per 100000 people, standardized by age.

\section{Results and discussion}

\subsection{Principal Component Analysis (PCA)}

Principal component analysis consists in highlighting the change of variables relative to others variables and how they are associated: converting correlated variables into a new set of uncorrelated variables using a covariance matrix or its standardized form.

The assessment of the quality of PCA results can be done by using the Kaiser-Meyer-Olkin statistical test (KMO) used to compare the magnitude of the correlation coefficients with the magnitude of the partial correlation coefficients (Table no. 2).

Table no. 2: Tests for the assumption of factorability

\begin{tabular}{|c|c|c|}
\hline Kaiser-Meyer-Olkin Measu & $\begin{array}{l}\text { Sampling Adequacy. } \\
\text { Approx. Chi-Square }\end{array}$ & $\begin{array}{r}.734 \\
344.248\end{array}$ \\
\hline Bartlett's Test of Sphericity & Df & 91 \\
\hline & Sig. & 000 \\
\hline
\end{tabular}

The value of Kaiser-Meyer-Olkin's sampling adequacy test is 0.734 , indicating an appropriate explanatory power of the indicators, and the value of the Bartlett Sphericity test of 344.248 with a significance threshold of 0.00 shows a significant difference in the matrix correlations between the variables considered therefore the matrix of correlations is not an identity matrix.

In addition to the advantage of synthesizing the initial set of indicators while preserving the maximum possible proportion of total variance in the original set of data, Principal Component Analysis presents, in this case, sensitivity to changes in baseline data and the presence of outliers (Table no. 3)

Table no. 3: Total variance explained

\begin{tabular}{|c|c|c|c|c|c|c|c|c|c|}
\hline \multirow{2}{*}{ 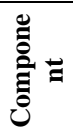 } & \multicolumn{3}{|c|}{ Initial Eigenvalues } & \multicolumn{3}{|c|}{$\begin{array}{c}\text { Extraction Sums of Squared } \\
\text { Loadings } \\
\end{array}$} & \multicolumn{3}{|c|}{$\begin{array}{c}\text { Rotation Sums of Squared } \\
\text { Loadings } \\
\end{array}$} \\
\hline & Total & $\begin{array}{c}\% \text { of } \\
\text { Variance }\end{array}$ & $\underset{\%}{\text { Cumulative }}$ & Total & $\begin{array}{c}\% \text { of } \\
\text { Variance }\end{array}$ & $\underset{\%}{\text { Cumulative }}$ & Total & $\begin{array}{c}\% \text { of } \\
\text { Variance }\end{array}$ & $\underset{\%}{\text { Cumulative }}$ \\
\hline 1 & 6.492 & 46.373 & 46.373 & 6.492 & 46.373 & 46.373 & 4.386 & 31.329 & 31.329 \\
\hline 2 & 2.655 & 18.965 & 65.339 & 2.655 & 18.965 & 65.339 & 4.079 & 29.136 & 60.465 \\
\hline 3 & 1.181 & 8.436 & 73.775 & 1.181 & 8.436 & 73.775 & 1.863 & 13.310 & 73.775 \\
\hline 4 & .984 & 7.029 & 80.804 & & & & & & \\
\hline 5 & .771 & 5.508 & 86.311 & & & & & & \\
\hline 6 & .555 & 3.967 & 90.279 & & & & & & \\
\hline 7 & .476 & 3.398 & 93.676 & & & & & & \\
\hline 8 & .269 & 1.918 & 95.594 & & & & & & \\
\hline 9 & .241 & 1.721 & 97.315 & & & & & & \\
\hline 10 & .170 & 1.213 & 98.528 & & & & & & \\
\hline 11 & .090 & .642 & 99.170 & & & & & & \\
\hline 12 & .062 & .441 & 99.611 & & & & & & \\
\hline 13 & .044 & .317 & 99.928 & & & & & & \\
\hline 14 & .010 & .072 & 100.000 & & & & & & \\
\hline
\end{tabular}

Extraction Method: Principal Component Analysis. 
In the PCA, the results obtained for calculating own values (Table no. 4) are sorted according to the variation of the variable they represent in the original data. Obviously, aggregation of new components represents $100 \%$ of the variation. The lack of correlation between the main components means that they measure different "statistical dimensions".

Because the individual indicators with similar values in all countries are of no interest because these cannot explain the different performance, the highest factor load is attributed to the primary indicators with the greatest variation of values between countries.

The 14 variables were grouped into three factors with own values greater than 1 , so in the context of the initial non-rotatable factorial solution, they explain $73.775 \%$ of the variance of the analyzed values and the $26.225 \%$ difference remains unexplained by this model.

After rotating the factors, even if the difference between the values of the factors has narrowed, it is found that the first factor best explains the variance of the variables. As can be seen (Table no. 3), a redistribution of the variance explained by each factor takes place, factor 1 loses from the degree of saturation in favor of factor 2 and factor 3 . Practically, the saturations value for each factor is changed under the conditions in which the value of the total variance remains unchanged.

The diagram leads to the retention of two or three components, the final decision being influenced by the cumulative proportion of the explained variance. If each variable is appreciated as a factor, from the graphical representation of the 14 factors (Figure no. 1) it can be considered that the first three components have the highest value.

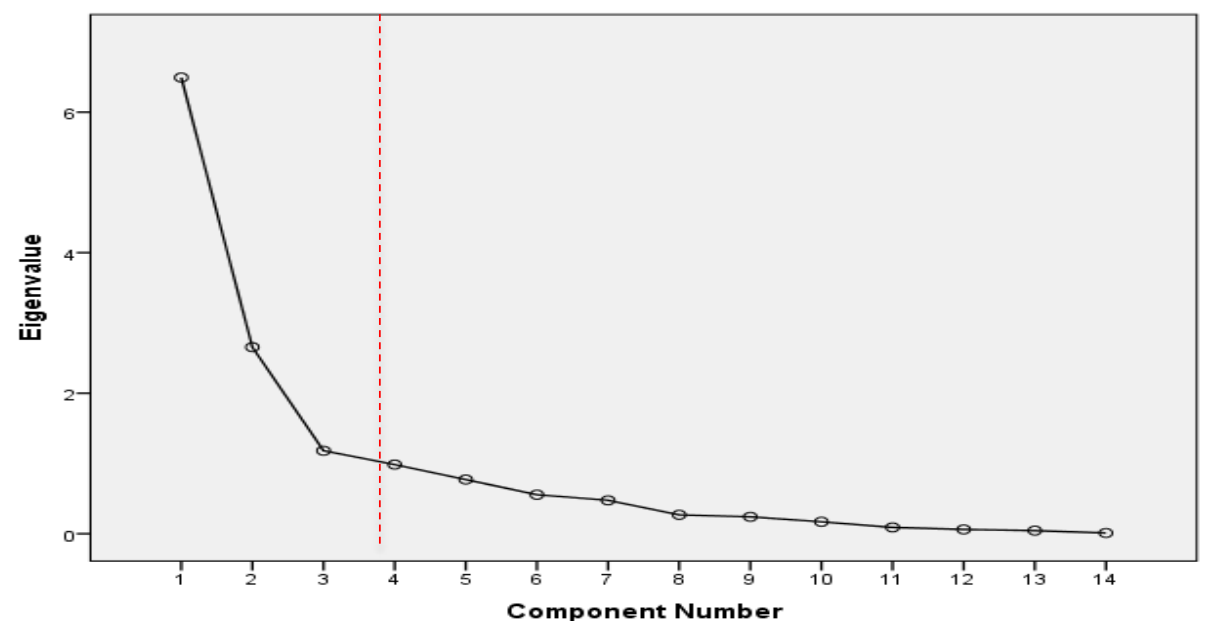

Figure no. 1: Eigenvalues diagram

The component matrix is useful in factorial analysis, but the more efficient structure for interpretation remains, however, the one obtained by turning factors, especially if it is taken into account that this provides a better "vision" for data interpretation. 
Table no. 4: Rotated Component Matrix

\begin{tabular}{|c|c|c|c|}
\hline \multicolumn{4}{|l|}{ Rotated Component Matrix ${ }^{\mathrm{a}}$} \\
\hline & \multicolumn{3}{|c|}{ Component } \\
\hline & 1 & 2 & 3 \\
\hline $\begin{array}{l}\text { Exposure to air pollution by particulate matter } \mu \mathrm{g} / \mathrm{m} 3 \\
\text { Particulates }<10 \mu \mathrm{m}(\operatorname{In} 2)\end{array}$ & .881 & & \\
\hline $\begin{array}{l}\text { Exposure to air pollution by particulate matter } \mu \mathrm{g} / \mathrm{m} 3 \\
\text { Particulates }<2.5 \mu \mathrm{m}(\mathrm{In} 1)\end{array}$ & .853 & & \\
\hline $\begin{array}{l}\text { Urban population exposed to PM10 concentrations exceeding the daily } \\
\text { limit value }(50 \mu \mathrm{g} / \mathrm{m} 3 \text { on more than } 35 \text { days in a year) } \% \text { (In } 4)\end{array}$ & .789 & & \\
\hline GDP per capita in PPS Index $($ EU28 = 100) $(\operatorname{In} 9)$ & -.742 & & \\
\hline $\begin{array}{l}\text { Outdoor air pollution attributable deaths (no. deaths/100000 people) } \\
\text { (In12) }\end{array}$ & .700 & .623 & \\
\hline Eco-innovation index $(\mathrm{EU}=100)(\operatorname{In} 8)$ & -.694 & & \\
\hline $\begin{array}{l}\text { Average } \mathrm{CO}_{2} \text { emissions per km from new passenger cars }-\mathrm{g} \mathrm{CO}_{2} \\
\text { per km (In5) }\end{array}$ & & .848 & \\
\hline $\begin{array}{l}\text { Causes of death - standardised death rate by residence Diseases } \\
\text { of the circulatory system (I00-I99) Total (In14) }\end{array}$ & & .800 & \\
\hline Life expectancy at birth by sex years (In10) & & -.759 & \\
\hline $\begin{array}{l}\text { Household air pollution attributable deaths (no. deaths/100000 people) } \\
\text { (In11) }\end{array}$ & & .672 & \\
\hline Greenhouse gas emissions $\left(\mathrm{CO}_{2}\right.$ equivalents per GDP) $(\operatorname{In} 7)$ & & .657 & \\
\hline $\begin{array}{l}\text { Greenhouse gas emissions Greenhouse gas emissions } \\
\text { (in } \mathrm{CO}_{2} \text { equivalent), base year } 1990 \text { (In3) }\end{array}$ & & -.656 & \\
\hline $\begin{array}{l}\text { Share of renewable energy in gross final energy consumption } \\
\text { by sector \% (In6) }\end{array}$ & & & -.911 \\
\hline $\begin{array}{l}\text { Causes of death - standardised death rate by residence Diseases } \\
\text { of the respiratory system (J00-J99) Total (In13) }\end{array}$ & & & .624 \\
\hline
\end{tabular}

It is noticed that the solution is obtained by a process of 5 iterations. From the total number of variables, we can extract as many components as required, each of its own values representing the part of variance explained by the component.

Depending on the saturation values of each variable, we identify the factors (Table no. 5). After rotating the factors, applying the Varimax method, are:

Table no. 5: Identifying Components after Factor Rotation

\begin{tabular}{|c|c|c|c|c|}
\hline Item & $\begin{array}{c}\text { Explanation } \\
\text { of the total }\end{array}$ & Variable & Saturation & $\begin{array}{c}\text { Factor } \\
\text { identification }\end{array}$ \\
\hline \multirow{4}{*}{1} & \multirow{4}{*}{$31.33 \%$} & $\begin{array}{l}\text { Exposure to air pollution by particulate } \\
\text { matter } \mu \mathrm{g} / \mathrm{m} 3 \text { Particulates }<10 \mu \mathrm{m} \text { (In2) }\end{array}$ & .881 & \multirow{4}{*}{$\begin{array}{l}\text { The air } \\
\text { pollution }\end{array}$} \\
\hline & & $\begin{array}{l}\text { Exposure to air pollution by particulate } \\
\text { matter } \mu \mathrm{g} / \mathrm{m} 3 \text { Particulates }<2.5 \mu \mathrm{m}(\operatorname{In} 1)\end{array}$ & .853 & \\
\hline & & $\begin{array}{l}\text { Urban population exposed to } \mathrm{PM}_{10} \\
\text { concentrations exceeding the daily limit } \\
\text { value }(50 \mu \mathrm{g} / \mathrm{m} 3 \text { on more than } 35 \text { days } \\
\text { in a year) } \%(\operatorname{In} 4)\end{array}$ & .789 & \\
\hline & & $\begin{array}{l}\text { GDP per capita in PPS Index }(\text { EU28 }=100) \\
(\operatorname{In} 9)\end{array}$ & -.742 & \\
\hline
\end{tabular}




\begin{tabular}{|c|c|c|c|c|}
\hline Item & $\begin{array}{c}\text { Explanation } \\
\text { of the total }\end{array}$ & Variable & Saturation & $\begin{array}{c}\text { Factor } \\
\text { identification }\end{array}$ \\
\hline & & $\begin{array}{l}\text { Outdoor air pollution attributable deaths } \\
\text { (no. deaths/100000 people) (In12) }\end{array}$ & .700 & \\
\hline & & Eco-innovation index $(\mathrm{EU}=100)(\operatorname{In} 8)$ & -.694 & \\
\hline \multirow{6}{*}{2} & \multirow{6}{*}{$29.14 \%$} & $\begin{array}{l}\text { Average } \mathrm{CO}_{2} \text { emissions per km from new } \\
\text { passenger cars }-\mathrm{g} \mathrm{CO}_{2} \text { per km (In5) }\end{array}$ & .848 & \multirow{6}{*}{$\begin{array}{l}\text { Traffic pollution } \\
\text { // } \\
\text { Impact of } \\
\text { urbanization on } \\
\text { health }\end{array}$} \\
\hline & & $\begin{array}{l}\text { Causes of death - standardised death rate by } \\
\text { residence Diseases of the circulatory system } \\
\text { (I00-I99) Total (In14) }\end{array}$ & .800 & \\
\hline & & Life expectancy at birth by sex years (In10) & -.759 & \\
\hline & & $\begin{array}{l}\text { Household air pollution attributable deaths } \\
\text { (no. deaths/100000 people) (In11) }\end{array}$ & .672 & \\
\hline & & $\begin{array}{l}\text { Greenhouse gas emissions (CO2 } \\
\text { equivalents per GDP) (In7) }\end{array}$ & .657 & \\
\hline & & $\begin{array}{l}\text { Greenhouse gas emissions Greenhouse gas } \\
\text { emissions (in } \mathrm{CO}_{2} \text { equivalent), base year } \\
1990 \text { (In3) }\end{array}$ & -.656 & \\
\hline \multirow[b]{2}{*}{3} & \multirow[b]{2}{*}{$13.31 \%$} & $\begin{array}{l}\text { Share of renewable energy in gross final } \\
\text { energy consumption by sector \% (In6) }\end{array}$ & -.911 & \multirow{2}{*}{$\begin{array}{l}\text { The impact of } \\
\text { renewable } \\
\text { energy on health }\end{array}$} \\
\hline & & $\begin{array}{l}\text { Causes of death - standardised death rate } \\
\text { by residence Diseases of the respiratory } \\
\text { system (J00-J99) Total (In13) }\end{array}$ & .624 & \\
\hline
\end{tabular}

Factor 1 - Outdoor air pollution. No matter how natural or rich a country is, air pollution is a difficult phenomenon to eliminate. Microscopic pollutants in the air, particulate matter: $\mathrm{PM}_{10}$ (particles with a diameter of 10 micrometers or less) and $\mathrm{PM}_{2.5}$ (particles with a diameter of 2.5 micrometers or less) can easily pass through our immune system, penetrating deep into the respiratory system and circulatory, damaging the lungs, heart and brain (Xing, et al., 2016). According to the World Health Organization's recommendations, the annual mean concentration is the best indicator for the health effects associated with PM.

This factor is strongly correlated with exposure to air pollution with particulate matter $\left(\mathrm{PM}_{10}\right.$ and $\mathrm{PM}_{2.5}$ ). Much of the population of European Union countries is subject to the effects of pollution. If in the short term, poor air quality can cause respiratory problems, on longer-term it can lead to chronic lung disease, asthma and, last but not least, can reduce life expectancy.

The European Union countries must report to the European Commission, in real time, updated air quality data. The use of modern technology for this purpose offers the possibility to keep the public informed.

In this regard, an example of good practice can be considered the site of the non-profit organization for air quality monitoring in Paris and in the Ile de France region, Airparif. In addition to data on air quality monitoring and pollution episodes forecasting, the organization assesses the impact of the measures implemented to reduce pollution and contributes to informing citizens. Ease of accessing data and space maps with forecasts for the next day, automatic alerts and mobile applications help anyone be able to check local air quality and take the necessary precautions to reduce pollution exposure. 
Factor 2 - The Impact of Urbanization on Health explains $29,136 \%$ of the total variation of baseline data and is strongly correlated with (In5) and (In14).

Within EU countries, major differences in air quality are not only influenced by pollution, but also by urbanization or by the use of natural resources. At the same time, the quality of the indoor environment is not only affected by the quality of air pollution in the environment but also by exposure to moisture, mold and other biological agents, has been linked to asthma and allergic symptoms, pulmonary cancer and other respiratory and cardiovascular diseases (European Environment Agency, 2010).

Since 2008, France has introduced the "feebate" type system for new cars. It imposes a charge on new vehicles that have a high level of $\mathrm{CO}_{2}$ and is one of the best policy options available to reduce the $\mathrm{CO}_{2}$ emissions of passenger cars. Thus, the bonus-malus system requires a tax on the buyer if the $\mathrm{CO}_{2}$ emissions of the vehicle exceed a certain threshold and offer bonuses if they are below a certain level (Ministère de la Transition écologique et solidaire, 2017). The results of the application of this system: the reduction of $\mathrm{CO}_{2}$ emissions in France and, at the same time, the trading of vehicles with low carbon emissions (Yang, 2018), makes this an example of good practices for the countries of the European Union.

Factor 3 explains $13,310 \%$ of the total variation of baseline data and is strongly correlated with In6 and In13, with a saturation level of -0.911 and 0.624 , respectively. The third component highlights the impact of mitigating climate change and air quality on health. Practically, energy changes and how energy is used can have negative health effects. Not only lack of access to adequate sources of energy can lead to obvious health problems but also to excessive use, which would lead to climate change.

All this can be found at the individual level, so Wilkinson analyzed in 2011 the influence of external temperature on cardiovascular disease deaths and showed a strong association between outdoor temperature and mortality in less energy efficient homes, highlighting the protective effect of warmer homes on health. On the other hand, improved energy efficiency or insulation does not only protect against cold, but also against high temperatures (avoiding overheating) and the penetration of harmful pollutants from outside air (Armstrong, et al., 2011). On the other hand, improved energy efficiency or insulation does not only protect against cold, but also against high temperatures (avoiding overheating) and the penetration of harmful pollutants from outside air (Mavrogiannia, et al., 2011), but neither protects against the risk of increasing the concentration of pollutants from internal sources.

Pollution of air with soot and carbon aerosol emissions resulting from the combustion of fossil fuels and biomass-burning leads to an increase in the number of people with respiratory or cardiovascular disease (Morishita, et al., 2015). Alternatives to the primary energy source used to produce electricity, with a lower negative impact on health, are nuclear energy (Markandya \& Wilkinson, 2007) or renewable energy. Regarding renewable energy - with less dangerous effects in the case of an accident than nuclear energy it can significantly reduce or eliminate carbon emissions (UNEP, 2009). Large-scale production of different types of energy would improve the quality of the environment through indirect land-use impacts related to bioenergy production and hydroelectric power generation (EC, 2000), can have a significant effect on the quality of life, and the placement of wind turbines and dams can reduce the impact on marine life and birds (European Environment Agency, 2010). 


\subsection{Cluster Analysis (CA)}

In this case, we applied a hierarchical grouping algorithm and the applied method is the one known as the furthest neighbor or the maximum distance method (Complete Linkage), this method defining the distance between two groups as the distance between the farthest members. This method usually generates well-separated and compact groups. Obviously, cluster analysis cannot be considered a test procedure for research assumptions, its solutions being sensitively influenced by the subjective options of the data analyst. Starting from a number of clusters equal to the number of cases studied, and after successive groups, we reach the final solution - a single cluster that includes all cases.

The final solution is not the optimal solution either. The latter is between the two situations and is set according to the proposed objectives.

In order to achieve a viable solution, it is necessary to analyze the characteristics of the clusters in successive stages. A solution is selected when we consider that it has reached an interpretable solution or there is a solution with a reasonable number of clusters or sufficiently homogeneous.

Considering that a single solution cannot be determined to solve a problem using cluster analysis, the validity of the cluster analysis results is given by the confirmation of the clustering solution used either by interpretive methods of graphical representations.

At 1st stage, Belgium is in the same cluster as the Netherlands (Annex no. 1), the square of the Euclidean distance between the two being equal to 2.072. No other variable has been grouped previously (value 0 on Cluster 1 and Cluster 2 in Stage Cluster First Appears) and the next step is Stage 5 (if the cluster containing Belgium combines with another case, i.e. France).

At the 4th stage, Hungary is in the same cluster as Romania (Annex no. 1) and the square of the Euclidean distance between the two is 4.986; in the next round the cluster will include Bulgaria, with 15.043 squares of the Euclidean distance between Hungary and Bulgaria.

Based on the graphical representation (Figure no. 2), resulting from the analysis of the data using the 14 variables - indicators presented previously (Table no. 1), we observe the highlighting of five clusters.

Cluster 1 - includes: Belgium, the Netherlands, France, Austria, Germany, Italy, Slovenia, Denmark, Great Britain, Ireland, Finland, Sweden and Luxembourg. It is the largest group and is strongly influenced by In8 and In9 indicators with the highest national averages, i.e. In8, In9 and In10, with the lowest national average for In11. Noteworthy Finland distinguished within this group by the smallest values of In1 and In2, Exposure to air pollution by particulate matter $\mu \mathrm{g} / \mathrm{m} 3$ Particles $<2,5 \mu \mathrm{m}$ and Particles $<10 \mu \mathrm{m}$ but also by the lowest Standardized rate of residence-related mortality due to respiratory disease (J00-J99) for the countries of the European Union (Annex no. 2).

Cluster 2 -includes: Portugal, Spain, Greece, Malta and Cyprus. In the ranking of the average values of the indicators is placed on the first position when we talk about life expectancy. Paradoxically, when analyzing the causes of death, it is at the top of the list if we refer to diseases of the circulatory system. On the other hand, a positive influence on In14 is that the average $\mathrm{CO} 2$ emissions per $\mathrm{km}$ of new passenger cars have the lowest average value, which 
is reflected in the fact that we also find the lowest average of the national values for the deaths of diseases of the respiratory system (Annex no. 2).

Cluster 3 - includes: Hungary, Romania, Bulgaria and is the highest average of In4, with the urban population being the most exposed to PM10 concentrations exceeding the daily limit value $(50 \mu \mathrm{g} / \mathrm{m} 3$ for more than 35 days in a year). This is reflected in the fact that we also find the highest exposure values to air pollution by particulate matter in $\mu \mathrm{g} / \mathrm{m} 3$ (Particles $<2.5 \mu \mathrm{m}$ and Particles $<10 \mu \mathrm{m}$ ). If it was still necessary, the lowest value of the national average for the Eco-Innovation Index corroborated the highest averages of the In11, In12 and In14 indicators, emphasizing the fact that in these countries, pollution is a factor that negatively impacts health (Annex no. 2).

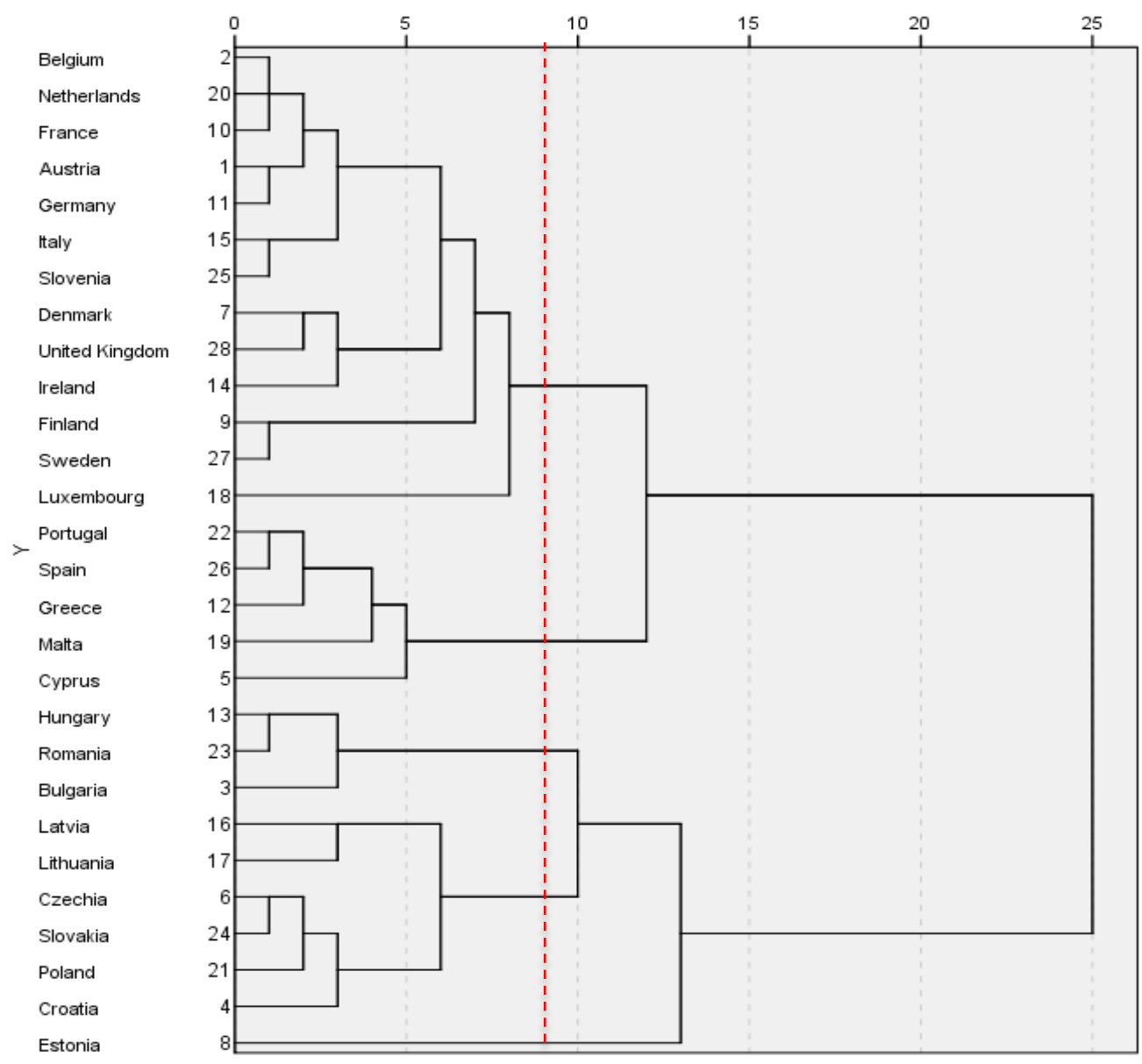

Figure no. 2: Dendogram

Special report 23/2018 published by the European Court of Auditors "Atmospheric pollution: our health is not yet sufficiently protected" underlines that "The European Environment Agency (EEA) estimates that (for 2014), in the European Union, 399000 of premature deaths can be attributed to exposure to fine particulate matter (PM2.5), 75000 exposure to nitrogen dioxide (NO2) and 13600 exposure to ozone from soil (O3). Although there are some 
overlaps between these figures (for example, $\mathrm{NO} 2$ is a precursor to PM2.5), so they cannot simply be summed up, they show that air pollution causes over 400,000 premature deaths in the EU annually" (European Court of Auditors, 2018, p. 68).

According to the country report on the implementation of the European Union's environmental policies, the air quality in Romania is still a serious concern (European Commission, 2019).

In Bucharest, in 2017, there were exceedances of the annual limit value for NO2 and with regard to suspended particles PM10 (European Commision, 2019, p. 19).

In addition to the fact that Bucharest is one of the most polluted cities in Europe, it also has the fewest air quality monitoring stations.

One of the solutions adopted by Romania for improving the air quality is the draft decision of the Local Council of the Municipality of Bucharest, which defines the Action Area for Air Quality (ZACA). It aims to reduce pollution by reducing the volume of traffic with personal cars and encouraging public and alternative transport (bicycles). Thus, an example of good practice can be considered the Draft Decision on concrete measures to improve the air quality in the municipality of Bucharest. Also called the OXIGEN project, it will restrict, from 01.01.2020, the access of vehicles with a mass of less than 5 tons inside ZACA, according to the pollution norm of each one. The measure adopted by the local authorities is a component of the Integrated Air Quality Plan and the Sustainable Urban Mobility Plan 2016-2030, and aims to improve the air quality in Bucharest. Other policies adopted by the local government to reduce the pollution of the environment are: the introduction of the payment regime of the parks of general public utility and the establishment of an optimum necessary of parking places, the construction of bicycle lanes on the main boulevards, the purchase of vehicles to European, modern and non-polluting for the provision of public transport etc.

Cluster 4 - includes: Latvia Lithuania Czech Republic, Slovakia Poland and Croatia. The fact that no indicator is characterized by any maximum or minimum value of the average of national values makes this class seem "good". But on an individual analysis of the countries included in this cluster, besides the country with the lowest life expectancy among the EU countries (Latvia), it is also comprised of the country with the lowest greenhouse gas emissions ( In3) and the urban population rate exposed to concentrations of PM10 exceeding the daily limit value (In4) of 0 (Lithuania). On the other hand, in cluster 4 we also find Poland, the most affected country when analyzing the exposure to air pollution by particulate matter in $\mu \mathrm{g} / \mathrm{m} 3$ Particles $<2.5 \mu \mathrm{m}$, In1 (Annex no. 2).

In 2014, Latvia launched a long-term strategy in transport policy as a policy to reduce $\mathrm{CO}_{2}$ emissions, reduce fossil fuel use and noise level. In this regard, the Ministry of Environmental Protection and Regional Development has provided financial support. for the implementation of such projects in which electric vehicles were purchased (Cansino, et al., 2018).

Cluster 5 - includes one country: Estonia. Compared with the mean values of the indicators that characterize the previous clusters, we find the lowest values for In1-In4, which makes this cluster have the lowest exposure to air pollution by particulate matter (Particles $<2.5 \mu \mathrm{m}$; Particles $<10 \mu \mathrm{m}$ ), least greenhouse gas emissions (in CO2 equivalent), base year 1990 and a 0 urban population rate exposed to PM10 concentrations exceeding the daily limit value (In4), which is reflected in the values for In12 and In13. It is the cluster with the highest share of renewable energy in gross final consumption of energy per sector but also with the highest 
average values of In5 (average $\mathrm{CO} 2$ emissions per $\mathrm{km}$ of new passenger cars) and In7 Greenhouse Gas Emissions - CO2 equivalent on GDP (Annex no 2).

In 2013, Estonia was the first member state of the European Union to extend free public transport to residents in its capital. The results of this approach can be highlighted in the short term - traffic decongestion, reducing the use of cars in Tallinn, etc., but also in the long term: reducing pollution and improving air quality by reducing carbon dioxide emissions - a reduction in $\mathrm{CO} 2$ emissions is expected. 45000 tons/year.

In practice, this decision by the Tallinn authorities encourages the use of public transport, thus reducing traffic congestion and emissions caused by cars and at the same time stimulating economic development (Eco-innovation Action Plan - European Commission, 2013).

Given the subjectivity of choosing the clusters (Figure no. 2) we can see that the first cluster, Luxembourg can be classified as an individual class, this country being characterized by an urban population exposed to PM10 concentrations exceeding the daily limit value $(50 \mu \mathrm{g} / \mathrm{m} 3$ per more 35 days in a year) at a rate of 0 , above the European Union average of the ecoinnovation and life expectancy index, below the EU average for In11, In12 and In13, and last but not least the fact that it has the highest GDP per capita.

Beyond these clusters, as a result of globalization, the climate crisis knows no borders. Countries inside European Union, along with their closest partners, will continue to lead the global work to combat it. Cooperation across borders to combat climate change is necessary and also feasible, building on the successful of environmental protection and air quality.

There are several activities and a range of measures in EU countries to protect natural areas, to guarantee air quality, to properly manage waste and to reduce the effects of harmful chemicals, generally speaking to improve the quality of environment.

\subsection{Best practices on improving air quality at EU level}

Awareness of the population regarding environmental issues and underlining the negative impact of a polluted environment on health is extensive processes that require a long period of time. In this sense, waste management practices are being used more and more and are being invested in the recycling and collection infrastructure.

The elaboration of policies that aim to optimize the methods and techniques to improve the air quality and the protection of the natural resources are based on the monitoring of the environment, particularly on the analysis of the pollution level. Thus, based on the information obtained from periodic analyzes, the practical actions of environmental management can be corrected by using good practices.

The existence of the particularities regarding the environmental policies and strategies at the country level makes each state treat differently the accomplishment of the sustainable development objectives. However, an exchange of good practices with EU countries that have performed the requirements of the EC Directive can only be welcomed.

An example of good practice is the regional program Neighborhoods (Quartiers Verts / Groene Wijken), started in 2000 in Belgium. As part of this project, it has been granted support in the Brussels region for more than 200 local greening initiatives. 
In France, a policy of good practice is represented by reducing traffic and air pollution by applying restrictions on old cars; through measures to improve pedestrian traffic in cities. Thus, starting with 2016, restrictions have been imposed on the circulation of older cars since 1997, and their movement in Paris between 8.00-20.00 is prohibited. Last but not least, it is forbidden to sell diesel and petrol cars until 2040.

Austria has adopted the Resource Efficiency Action Plan as an environmental improvement measure. Thus, manning compared to 2008, the aim is to optimize the global resource efficiency by 2020 with $50 \%$.

At the same time, Austria is one of the countries of the European Union with good practices applied in the field of circular economy and eco-innovation. In this regard, the Conscious Buy initiative ("Bewusst kaufen") aims, through a web portal, in addition to informing the population about sustainable consumption and its awareness of sustainable products.

The Green Laboratory of Recycling (2012) project is an example of good practices, developed by Eco-Rom Ambalaje, with the purpose of informing, educating and raising awareness of the young generation on environmental issues. An important contribution to the project was, on the one hand, the partnership with local municipalities, and on the other hand the involvement of school staff in promoting recycling.

Developed in partnership with the Ministry of Environment and the Ministry of Education, this project involves parents and teachers in educating and empowering children in the environment. The current and innovative character of the project was also recognized by awarding prizes and medals at national and international level: National Energy Globe Award; Golden Award for Excellence - within the European CSR Awards competition, Small and Medium Business category; silver medal in the Business Award (IBA) competition (Ecoromambalaje.ro, 2019).

\section{Conclusions}

Detailed analysis of the evolution of sustainable development, especially the environment and air quality, is needed to address health risks. A priority is also the development of effective solutions for achieving sustainable development objectives related to reducing air pollution and health risks.

At the same time, to achieve an Agenda 2030 objective, it is necessary to continue air quality monitoring to determine the degree of pollution, to reduce the number of deaths caused by air pollution by two-thirds until 2030. In addition to the obvious improvement in quality of life, this aspect will also mean reducing health care costs.

In order for all countries, including cities, to reach the levels suggested by WHO on air quality, innovative technologies in the field must be used, the use of renewable energy technologies and ecological fuels promoted, together with solutions for reducing or eliminating fertilizer use in agriculture, with the decrease of the fuel consumption that causes increased gas emissions and the stopping of the uncontrolled burning of the waste.

The results of the present research must be interpreted in the context of the existing limitations, generated by: the availability of air quality data obtained in a unitary and realtime manner for all the states of the European Union; reduced concerns regarding international regulations regarding indoor air quality in the context where $90 \%$ of the time is 
spent inside buildings (Ścibor, et al., 2019). Thus, the occupants of the buildings are persons exposed to a series of indoor air pollutants, of organic and inorganic nature, which can cause serious health effects (Koivist, et al., 2019).

A good practice policy adopted to improve indoor air quality is represented by the regulation regarding smoking inside buildings. Smoking bans, even if they have sparked controversy, have improved indoor air quality. Thus, pollutants caused by tobacco smoke in the indoor environment are decreasing. In Romania, Law no. 15/2016 to prevent and combat the consumption of tobacco products, prohibits smoking in confined spaces at work and in closed public spaces, aims to protect the health of employees and citizens living in public spaces, by avoiding exposure to cigarette smoke.

The negative effects of atmospheric pollutants are not limited solely to health, but are also reflected in high economic costs.

Further research aims to extend the sample globally, but also to include other variables. In addition, depending on the possibilities of accessing the specific data series, the study can also be applied at the level of the regions of Romania, highlighting good practices on how air quality can be improved by adopting better solutions for urban mobility.

\section{References}

Arbex, M.A., et al., 2012. Air pollution and the respiratory system. Jornal Brasileiro de Pneumologia, 38(5), pp. 643-655.

Armstrong, B., et al., 2011. Association of mortality with high temperatures in a temperate climate: England and Wales. Journal of Epidemiology \& Community Health, 65(4), pp. $340-345$.

Barnett, A.G., et al., 2006. The Effects of Air Pollution on Hospitalizations for Cardiovascular Disease inElderly People in Australian and New Zealand Cities. Environmental health perspectives, 114(7), pp. 1018-1023.

Cansino, J., Sánchez-Braza, A. and Sanz-Díaz, T., 2018. Policy Instruments to Promote Electro-Mobility in the EU28: A Comprehensive Review. Sustainability, 10(7), p. 2507.

Chow, C.K., et al., 2009. Environmental and societal influences acting on cardiovascular risk factors and disease at a population level: a review. International Journal of Epidemiology, 38(6), pp. 1580-1594.

Eco-innovation Action Plan - European Commission, 2013. Tallinn becomes "capital of free public transport" - Eco-innovation Action Plan - European Commission. [online] Available at: <https://ec.europa.eu/environment/ecoap/about-eco-innovation/goodpractices/estonia/20130617-capital-of-free-public-transport_en> [Accessed 6 August 2019].

Ecoromambalaje.ro, 2019. Laboratorul verde al reciclarii obtine national energy globe award. Eco-rom ambalaje. [online] Available at: <https://colecteazaselectiv.ro/ laboratorul-verde-al-reciclarii-2/> [Accessed 17 August 2019].

EC, 2000. Directive 2000/60/EC of the European Parliament and of the Council of 23 October 2000 establishing a framework for Community action in the field of water policy, s.l.: EC of the European Parliament and of the Council. 
European Commission, 2012. Communication from the Commission to the European Parliament, the Council, the European Economic and Social Committee and the Committee of the Regions: Innovating for sustainable growth: a bioeconomy for Europe. Brussels: European Commission.

European Commission, 2016. The junction of health, environment and the bioeconomy Foresight and implications for European research \& innovation policies - Study. Brussels: European Commission.

European Commission, 2018. Report from the commission to the European parliament and the council on the implementation of the EU Strategy on adaptation to climate change. Brussels: European Commission, Directorate-General for Climate Action.

European Commission, 2019. The 2019 assessment of the implementation of EU environmental policies. Bruxelles: European Commission.

European Court of Auditors, 2018. Air pollution: our health is not yet sufficiently protected, s.l.: European Court of Auditors.

European Environment Agency, 2010. The European environment. State and outlook 2010: synthesis. Copenhaga: European Environment Agency (EU body or agency).

European Environment Agency, 2017. Climate change adaptation and disaster risk reduction in Europe. Enhancing coherence of the knowledge base, policies and practices - Study. Luxemburg: Publications Office of the European Union.

Eurostat, 2018. Database - Eurostat. [online] Available at: <https://ec.europa.eu/eurostat/data/database> [Accessed 20 June 2019].

Eurostat, 2019. SHARES (Renewables) - Eurostat. [online] Available at: <https://ec.europa.eu/eurostat/web/energy/data/shares> [Accessed 20 June 2019].

Institute of Medicine (US), 2001. Rebuilding the Unity of Health and the Environment: A New Vision of Environmental Health for the 21st Century. Washington (DC): National Academies Press (US).

Intergovernmental Panel on Climate Change, 2007. Climate Change 2007: Mitigation. Contribution of Working Group III to the Fourth Assessment Report of the Intergovernmental Panel on Climate Change [B. Metz, O.R. Davidson, P.R. Bosch, R. Dave, L.A. Meyer (eds)]. Cambridge and New York: Cambridge University Press.

Kampa, M. and Castanas, E., 2008. Human health effects of air pollution. Environmental Pollution, 151(2), pp. 362-367.

Kiesewetter, G., et al., 2015. Modelling street level PM10 concentrations across Europe: source apportionment and possible futures. Atmospheric Chemistry and Physics, 15(3), pp. 1539-1553.

Koivist, A.J., et al., 2019. Source specific exposure and risk assessment for indoor aerosols. Science of The Total Environment, Volume 668, pp. 13-24.

Makria, A. and Stilianakis, N.I., 2008. Vulnerability to air pollution health effects. International journal of hygiene and environmental health, 211(3-4), pp. 326-336.

Markandya, A. and Wilkinson, P., 2007. Energy and Health 2. Electricity generation and health. The Lancet, 370(9591), pp. 979-990.

Mavrogiannia, A. et al., 2011. Building characteristics as determinants of propensity to high indoor summer temperatures in London dwellings. Building and Environment, Volume 55, pp. 117-130. 
Meyer, R., 2017. Bioeconomy Strategies: Contexts, Visions, Guiding Implementation Principles and Resulting Debates. Sustainability, 9(6), p. 1031.

Ministère de la Transition écologique et solidaire, 2017. Bonus-malus écologique: définitions et barèmes pour 2018. [online] Available at: <https://www.ecologique-solidaire.gouv.fr/ bonus-malus-ecologique-definitions-et-baremes-2018> [Accessed 29 July 2019].

Morishita, M., Thompson, K. and Brook, R.D., 2015. Understanding Air Pollution and Cardiovascular Diseases: Is It Preventable?. Current Cardiovascular Risk Reports, 9(6), p. 30.

Nakano, T. and Otsuki, T., 2013. Environmental air pollutants and the risk of cancer. Gan To Kagaku Ryoho, 40(11), pp. 1441-1445.

Pruss-Ustun, A. et al., 2016. Preventing disease through healthy environments. A global assessment of the burden of disease from environmental risks, s.1.: World Health Organization.

Ronzon, T. et al., 2016. Bioeconomy Report, Brussels: JRC Scientific and Policy Report.

Ścibor, M. et al., 2019. Are we safe inside? Indoor air quality in relation to outdoor concentration of PM10 and PM2.5 and to characteristics of homes. Sustainable Cities and Society, Volume 48, p. 101537.

Social Progress Imperative, 2019. 2019 Social Progress Index. [online] Available at: <https://www.socialprogress.org/> [Accessed 30 July 2019].

UNEP, 2009. Towards sustainable production and use of resources: assessing biofuels Summary. Paris: United Nations Environment Programme.

United Nations, 1987. Montreal Protocol on Substances that Deplete the Ozone Layer. [online] Available at: <https://treaties.un.org/doc/Publication/MTDSG/Volume\%20II/ Chapter\%20XXVII/XXVII-2-a.en.pdf > [Accessed 30 July 2019].

Wendling, Z.A. et al., 2018. 2018 Environmental Performance Index (EPI). New Haven: Yale Center for Environmental Law \& Policy.

WHO Working Group on Volatile Organic Compounds (1995: Brussels, Belgium) \& World Health Organization. Regional Office for Europe, 1996. Updating and revision of the air quality guidelines for Europe: report on a WHO Working Group on Volatile Organic Compounds, Brussels, Belgium, 2-6 October 1995, Copenhagen: WHO Regional Office for Europe.

World Health Organization, 1948. Constitution of the World Health Organization. New York: World Health Organization.

World Health Organization, 1958. Air pollution: fifth report of the Expert Committee on Environmental Sanitation [meeting held in Geneva from 18 to 23 November 1957]. Geneva: World Health Organization.

WWF and Ecofys, 2011. EU Climate Policy Tracker. Brussels: WWF-World Wide Fund for Nature.

Xing, Y.F., Xu, Y.H., Shi, M.H. \& Lian, Y.X., 2016. The impact of PM2.5 on the human respiratory system. Journal of thoracic disease, 8(1), pp. E69-74.

Yang, Z., 2018. Practical lessons in vehicle efficiency policy: The 10-year evolution of France's CO2-based bonus-malus (feebate) system. [Online] Available at: $<$ https://theicct.org/blog/staff/practical-lessons-vehicle-efficiency-policy-10-yearevolution-frances-co2-based-bonus> [Accessed 27 July 2019]. 
Appendix no. 1

\section{Agglomeration Schedule}

\begin{tabular}{|c|c|c|c|c|c|c|}
\hline \multirow{2}{*}{ Stage } & \multicolumn{2}{|c|}{ Cluster Combined } & \multirow{2}{*}{ Coefficients } & \multicolumn{2}{|c|}{ Stage Cluster First Appears } & \multirow{2}{*}{ Next Stage } \\
\hline & Cluster 1 & Cluster 2 & & Cluster 1 & Cluster 2 & \\
\hline 1 & 2 & 20 & 2.072 & 0 & 0 & 5 \\
\hline 2 & 6 & 24 & 3.132 & 0 & 0 & 9 \\
\hline 3 & 22 & 26 & 4.042 & 0 & 0 & 10 \\
\hline 4 & 13 & 23 & 4.986 & 0 & 0 & 17 \\
\hline 5 & 2 & 10 & 5.197 & 1 & 0 & 12 \\
\hline 6 & 15 & 25 & 5.281 & 0 & 0 & 15 \\
\hline 7 & 9 & 27 & 5.558 & 0 & 0 & 22 \\
\hline 8 & 1 & 11 & 5.824 & 0 & 0 & 12 \\
\hline 9 & 6 & 21 & 7.249 & 2 & 0 & 16 \\
\hline 10 & 12 & 22 & 8.357 & 0 & 3 & 18 \\
\hline 11 & 7 & 28 & 9.357 & 0 & 0 & 13 \\
\hline 12 & 1 & 2 & 10.425 & 8 & 5 & 15 \\
\hline 13 & 7 & 14 & 10.777 & 11 & 0 & 20 \\
\hline 14 & 16 & 17 & 11.452 & 0 & 0 & 21 \\
\hline 15 & 1 & 15 & 12.398 & 12 & 6 & 20 \\
\hline 16 & 4 & 6 & 14.999 & 0 & 9 & 21 \\
\hline 17 & 3 & 13 & 15.043 & 0 & 4 & 24 \\
\hline 18 & 12 & 19 & 15.409 & 10 & 0 & 19 \\
\hline 19 & 5 & 12 & 19.980 & 0 & 18 & 25 \\
\hline 20 & 1 & 7 & 25.702 & 15 & 13 & 22 \\
\hline 21 & 4 & 16 & 27.147 & 16 & 14 & 24 \\
\hline 22 & 1 & 9 & 30.199 & 20 & 7 & 23 \\
\hline 23 & 1 & 18 & 36.079 & 22 & 0 & 25 \\
\hline 24 & 3 & 4 & 43.316 & 17 & 21 & 26 \\
\hline 25 & 1 & 5 & 50.562 & 23 & 19 & 27 \\
\hline 26 & 3 & 8 & 54.419 & 24 & 0 & 27 \\
\hline 27 & 1 & 3 & 110.811 & 25 & 26 & 0 \\
\hline
\end{tabular}

\section{Appendix no. 2}

Description of clusters using average values

\begin{tabular}{|c|r|r|r|r|r|}
\hline Nr. cluster & \multicolumn{1}{|c|}{$\mathbf{1}$} & \multicolumn{1}{c|}{$\mathbf{2}$} & \multicolumn{1}{c|}{$\mathbf{3}$} & \multicolumn{1}{|c|}{$\mathbf{4}$} & \multicolumn{1}{|c|}{$\mathbf{5}$} \\
\hline Component (no. Of countries) & \multicolumn{1}{|c|}{13} & \multicolumn{1}{c|}{5} & \multicolumn{1}{c|}{3} & 6 & 1 \\
\hline IN1 & 11.55 & 13.52 & 21.70 & 17.73 & 5.30 \\
\hline IN2 & 18.01 & 24.04 & 30.13 & 25.90 & 10.50 \\
\hline IN3 & 85.65 & 114.84 & 56.20 & 61.37 & 48.60 \\
\hline IN4 & 4.50 & 26.17 & 52.67 & 40.71 & 0.00 \\
\hline IN5 & 117.13 & 112.34 & 124.13 & 124.52 & 132.80 \\
\hline IN6 & 21.41 & 15.79 & 18.84 & 21.55 & 29.21 \\
\hline IN7 & 216.72 & 250.47 & 336.07 & 303.24 & 621.85 \\
\hline IN8 & 115.38 & 85.00 & 55.33 & 74.17 & 62.00 \\
\hline IN9 & 129.08 & 83.40 & 60.00 & 73.67 & 79.00 \\
\hline IN10 & 81.85 & 82.20 & 75.37 & 77.15 & 78.40 \\
\hline IN11 & 0.58 & 0.61 & 13.55 & 4.81 & 9.00 \\
\hline IN12 & 17.09 & 19.27 & 56.93 & 42.58 & 15.02 \\
\hline IN13 & 84.83 & 113.07 & 80.83 & 68.79 & 42.88 \\
\hline IN14 & 377.79 & 319.52 & 956.66 & 619.94 & 665.68 \\
\hline
\end{tabular}

